\title{
MISR 1 AND MISR 2: TWO NEW, HIGH YIELDING AND RUST RESISTANT BREAD WHEAT CULTIVARS
}

A.A. Hamada, S.E. Abd El-Majeed, E.A M. El-Saied, M.B. Tawfeles, H.S.A. ElBorhamy, W.A.M. El-Awady, S.H. Abo El-Ela, R.M.A. Kombor, A.A. Sewelam, I.A. Ameen, S.A.M. Seleem, S.M. Hassan, S.M.A. Abd El-Dayem, S.M. Hammad, M.E. Abd El-Rahman, S.A. El-Sawy, M. Abd El-Samad, M.A.M.A. El-Maghraby, A.M.Abd El-Al, M.Y. Ghoneam, A.A. Mourad, H.M. El-Gharabawy, A.T.H.Moustafa, T.H. Abd El-Salam, A.A. Hagrass, M.A. Aglan, E.A.M. Abd El-Hameed, Kh.I.M. Gad, W.Z.E. Farahat, Kh. E. Ibraheem, M.M. Zakaria, M.S.M. Mahmoud, A.M. Morssy, A.A.M. Hassan, I.S.M. Abd El-Lateef, S.N. Nathan, M.N.T. Abd El-Kader, E.Gh. Galal, M.M.M. Abd El-Salam, S.T. Eissa, G.A. Nour El-Dien, M.Y.M.Yossef, M.A.H. Darweesh, A.S. Abd El-Hameed, A.G. Abd El-Rady, M.M. Mohamed, M.M.M. Gab Alah, M.N.A. El-Hawary, M.S. Salous, A.A. Zein El-Abdeen, S.A. Mohamed, M.T. Shehab El-Dien, M.M.M. Yasseen, A.I. Abd El-Sadek, E.L. Elmassry, A.M.S. Sharshar, E.E. Moawad, Y.S.I. Kobessy, Y.M. Faltaos, Y.A. El-Gohary, G.M.M. Soliman, M.S.A. Gendy, A.A. Gomaa, E.H. Ghanem, M.G. Mosaad, A.H. Abd ElLateef, N.S. Hanna, S.A. Ali, M.A.M. Eed, M.E.E. Saleh, M.A.Gouda, F.A.M. Hefnawy, A.A. Egeez, N.R. Abd El-Fatah, M.A. Moustafa, T.M. Shehab El-Dien, A.A. El-Hag, M.A.M. Abo Shereef, S.R.S. Sabry, M.M.M. AbdelAleem, M.S.A. Sharshar, A.M. Gad Alah, G.A.M. Sharawy, I.M.M. Sadek, A.M. Tammam, M.A. Ismaiel, N.A. Reiad, A.M.M. Moussa, H.I. Hendawy, R..A. Ramadan, A.M.A. Abo Warda, H.A.H. Ashoush, M. Soliman. I. Imbaby *and M.M El- Shamy*.

Wheat Res. Dept. Field Crops Res. Inst., ARC, Giza 12619, Egypt.

*Wheat Diseases Res. Dept., Plant Pathology Research Institute, ARC, Giza Egypt.

Received: Jan. 31, 2017

Accepted: Mar. 5, 2017

ABSTRACT: Two newly bread wheat cultivars Misr 1 and Misr 2 were selected from CIMMYT wheat genotypes as resistant to stem rust specially the race Ug 99. Grain yield and rust resistance evaluation was performed through preliminary, advanced and varietal verification started in 2009/2010 through 2012/2013 growing seasons, compared to the check bread wheat cultivated cultivars. The results reveled that the grain yield of Misr 1 and Misr 2 exceeded wheat check cultivars in most of the tested locations. Generally, the new cultivars mean grain yield exceeded all the check cultivars means in preliminary, advanced and varietal verification yield trials and have high stable parameters allover the wheat cultivated areas. Testing the two new cultivars for stem and yellow rusts reaction, in the hot spots in Egypt, Uganda, Kenya and Ethiopia, indicated their resistance to stem and yellow rusts. Thus they could be highly recommended to be grown all over Egypt.

Key words: Stem rust, Ug 99, rust resistance, grain yield, evaluation and bread wheat.

\section{INTRODUCTION}

Wheat has been the first strategic food crop in Egypt for more than thousands of years. It has maintained as the basic stable food in urban and rural areas for bread making. However, stem rust caused by Puccinia graminis tritici is causing considerable losses in grain yield.
Resistant sources to stem rust were introduced from Kenya and crossed to the Egyptian cultivars and the first stem rust resistant cultivar released in 1947 was Giza 139 (Hindi 90/Kenya B256), followed by Giza 144, Giza 145, Giza 147, Giza 148 and Giza 150. These cultivars were followed by the cultivar Giza 155 which 
was resistant to yellow rust. In early 1970 s materials from the International Maize and Wheat Improvement Center (C1MMYT) in Mexico were introduced. Wheat lines introduced from CIMMYT provided different genes for resistance. The new cultivars were resistant, and stem rust was successfully controlled for the last 50 years due to widespread use of resistant cultivars early maturing cultivars, pathogen stability and no aggressive races and absence of the alternate host.

A new stem rust race virulent to the resistance gene $\mathrm{Sr} 31$ was detected in Uganda in 1999 (Pretorius et al, 2000) and named Ug99. CIMMYT in 2005 reported that Ug99 was likely to spread beyond the borders of the three East African countries and it is a matter of time before it spread to the Arabian Peninsula and beyond. Therefore, Egypt was considered one of the countries under risk to the spread of Ug99, because most of wheat genotypes are CIMMYT germplasm. Therefore, Wheat Research Department (WRD), Field Crops Research Institute (FCRI), Agricultural Research Center (ARC) in Egypt, addressed the problem and initiated research strategy to avoid losses in wheat grain yields might caused by race Ug99. The strategy based on introducing wheat genotypes resistant to Ug99, testing breeding materials in the hot spots (Ethiopia and Kenya), incorporating resistance genes to local cultivars and releasing new resistant cultivars with high yield potential over the dominating cultivars.

According to that, WRD is using to send its genetic materials annually to Ethiopia and Kenya to be tested for their resistance to stem rust and introducing genetic germplasm resistant to stem rust race tested in Kenya by CIMMYT, especially to the race $\mathrm{Ug} 99$.

The first stem rust nursery introduced from CIMMYT was the "2 ${ }^{\text {nd }}$ EBWYT" in 2006/2007 growing season, to select resistant genotypes with higher yield potential than the most recent commercial cultivars.

Wheat Research Department released many high yielding bread wheat cultivars and resistance to rust diseases as Sakha 93 and Giza 168 (Shehab El-Din et al 1999), Gemmeiza 9 which proved its superiority in grain yield over its resistance to rust diseases (Mosaad et al., 2000), and continue to develop high-yield varieties resistant to diseases up to the year 2015 where the bread wheat cultivar Giza 171 was released (Hamada et al 2015).

The objective of this work is to assess grain yield and stability parameters for the new bread wheat cultivars Misr 1 and Misr 2 compared to the superior Egyptian commercial wheat cultivars in old and new reclaimed areas in Egypt.

\section{MATERIALS AND METHODS}

The new promising cultivars Misr 1 and Misr 2 were selected from the materials introduced from CIMMYT under the name of "2 ${ }^{\text {nd }}$ EBWYT 2006/2007" to the Wheat Research Department (WRD), Field Crops Research Institute (FCRI), Agricultural Research Center (ARC), Egypt. The pedigree and the selection history of the two new cultivars are:

Misr 1 = OASIS/SKAUZ//4*BCN/3/2*PASTOR CMSS00Y01881T-050M-0304-030M-

030WGY- 33M-0Y-0S.

Misr 2 = SKAUZ/BAV92

CMSS96M03611S-1M-0105Y-010M010SY-8M-OY-OS

In the two growing seasons of 2009/2010 and 2010/2011, the two new cultivars were tested against natural infection of stem rust under hot spots in Egypt, at Kafr El-Hamam, Nubaria and Sids in 2009/2010 and at Sakha , Gemmeiza, Kafr El-Hamam, Nubaria, El-Bostan, Sids, Mallawy and Shandaweel In 2010-2011. These two cultivars were tested at the same time and in parallel with testing the two new cultivares in 
African countries (Uganda, Kenya and Ethiopia) whereas the stem rust disease race $\mathrm{Ug} 99$ is diffused.

\section{Grain yield evaluation:}

After testing the two new cultivars for natural infection with rust diseases in hot places in Egypt and in Uganda, Kenya and Ethiopia and proven their resistance to rusts particularly stem rust race $\mathrm{Ug} 99$, and to accelerate releasing them, the grain yield evaluation was done in the preliminary yield trials (9 trials) conducted at nine research stations representing different ecological zones of wheat growing regions at over all the country; Sakha, Itay El-Barod, Kafr ElHamam, El-Gemmeiza, Sids, Mallawy, Shandaweel, El-Matanaa and El-Nubaria in the growing season (2011/2012). The advanced yield trials (25 trials in two growing seasons) were tested at 8 trials in 2010/2011 at Sakha, Gemmeiza, Kafr ElHamam, Sids, Mallawy, Shandaweel, Noubaria and Boustan. Again the new cultivars were tested in 2011/2012 growing season at 17 locations; Sakha, Etai ElBaroud, Gemmeiza, Sers El-Laian, Tag ElEzz, Kafr El-Hamam, Bahteem, Sids, Mallawy, Shandaweel, Mattana, Kom Ombo, Noubaria, New Valley, Assiut, Sharq ElEwynat and Ismaelia . The varietal verification trials were done in 2010/2011 through 2012/2013 growing season (89 trials) with the dominating bread wheat cultivars.

The experimental plot area of the preliminary yield trials was $4.2 \mathrm{~m}^{2}$ (6 rows $\mathrm{x}$ $3.5 \mathrm{~m}$ long and $20 \mathrm{~cm}$ apart) with 50 $\mathrm{kg} / \mathrm{feddan}$ seeding rate, in advanced yield trials it was $10.5 \mathrm{~m}^{2}(3 \mathrm{~m} \times 3.5 \mathrm{~m})$ and it was $100 \mathrm{~m}^{2}(10 \mathrm{~m} \times 10 \mathrm{~m})$ in the varietal verification yield trials, with $60 \mathrm{~kg} / \mathrm{feddan}$ seeding rate for both trials. All other recommended cultural practices for each region were applied on all trials.

At harvesting time, all of the experimental areas were harvested and threshed. The clean kernels of each plot were weighed to estimate the grain yield and adjusted to ardab/feddan.

The statistical design used in all trials was the Randomized Complete Block (RCBD) with four replicates, and statistical analyses were done according to Steel and Torrie (1960). Varietal verification yield trials have not been statistically analyzed, and there grain yields per feddan accounted on the basis of the yield of planted area and adjusted to the feddan

\section{Grain yield stability:}

Stability parameters for grain yield of the advanced yield trials were calculated according to Eberhart and Russell (1966).

\section{Rust Diseases Reaction: Seedling tests:}

The new cultivars Misr 1 and Misr 2 were tested against the prevalent virulent pathotypes of leaf and stem rusts in 2011/2012 growing seasons. The pathotypes used were isolates number 57 , $\mathrm{TI}$, and 184 of leaf rust and 11, 14, 15, 17, 19 and 39 of stem rust. Moreover, seedling tests for stripe rust resistance were made in the greenhouse at Sakha Research Station using a mixture of uredinial spores collected from the pathotypes attacked wheat last season, inoculation with uredinial spores of the different isolates, incubation and recording the infection types were carried out in the green house of the Cereal Diseases Research Department, Plant Pathology Research Institution at Giza according to the scales of Johnston and Browder (1966) and Roelfs and Martens (1988).

\section{Adult Tests:}

Leaf and stem rust disease incidences were recorded at the five locations in Sakha, El-Gemmeiza, Nubaria, Kafr El-Hamam and Sids Agricultural research stations under artificial inoculation of mixed isolates from each pathogen. For stripe rust, the cultivar was subjected to natural infection under field conditions. The average of rust disease 
Hamada, et al.,

severities were calculated and compared to the wheat cultivars Sids 12 , Sids 13 and Gemmeiza 11 in the advanced yield trials in 2011/2012 growing season.

Disease severity expressed as \% coverage of leaves with rust pustules and plant reaction for the five infection types $0=$ immune, $\mathrm{R}=$ resistant, $\mathrm{MR}=$ moderately resistant, $\mathrm{MS}=$ moderately susceptible and $\mathrm{S}=$ susceptible, according to Stakman et al (1962). Moreover, average Coefficient of Infection ( $\mathrm{ACl}$ ) was calculated using the scale of Saari and Wilcoxson (1974) in which $0=0, R=0.2, M R=0.4, M$ (Mixed reaction $)=0,6, M S=0,8$ and $S=1,0$.

\section{RESULTS AND DISCUSSION Grain yield evaluation:}

The results in Table 1 show the grain yield of the new cultivars Misr 1 and Misr 2 and the bread wheat commercial Sakha 93, Giza 168 and Sids 12 in the preliminary stem rust resistance yield trials in 2009/2010 growing season. The results showed that the grain yield (ardab/feddan) of the new bread wheat cultivars Misr1 and Misr2 exceeded the yield of all the check cultivars at Sids and Nubaria, as well as the check means all over the tested locations. The average increases in grain yield of the Misr 1 were $4.1,4.1$ and $7.8 \%$ and those of Misr 2 were $4.6,4.6$ and $8.4 \%$ over the means of the respective three check cultivars.

Moreover, the results of the advanced trials presented in Table 2 showed that the grain yield (ardab/feddan) of the new bread wheat cultivars when they tested in the advanced stem rust resistance yield trials at in 2010/2011 growing season. Misr 1 out yielded the check cultivars Sakha 93 and Giza 168 at all the tested locations except Giza 168 in Boustan location. Also, Misr 2 out yielded the check cultivars Sakha 93 and Giza 168 at all the tested locations except Sakha 93 at Sakha location. However, the average increases in grain yield of the Misr 1 were 15.8 and $8.5 \%$ and those of Misr 2 were 23.0 and $16.1 \%$ over the means of the respective two check cultivars.

The results in Table 3 showed that grain yield of the new bread wheat cultivars; Misr 1 and Misr 2 compared to the commercial and high yielding wheat cultivar Sids 12 in the preliminary yield trials conducted at nine locations in 2011/2012 growing season.

Table 1: Grain yield (ardab/feddan) of the preliminary yield trials in 2009/2010 growing season.

\begin{tabular}{|l|c|c|c|c|}
\hline \multirow{2}{*}{ Cultivar } & \multicolumn{3}{|c|}{ Locations } & \multirow{2}{*}{ Mean } \\
\cline { 2 - 4 } & Kafr El-Hamam & Sids & Noubaria & \\
\hline Misr 1 & 23.33 & 28.47 & 15.39 & 22.40 \\
\hline Misr 2 & 22.33 & 29.20 & 16.02 & 22.52 \\
\hline Sakha 93 & 22.67 & 27.13 & 14.77 & 21.52 \\
\hline Giza 168 & 24.00 & 26.72 & 13.84 & 21.52 \\
\hline Sids 12 & 23.67 & 28.55 & 10.11 & 20.78 \\
\hline Mean & 23.20 & 28.01 & 14.03 & 21.75 \\
\hline LSD 5\% & 4.99 & 5.66 & 5.02 & 5.18 \\
\hline
\end{tabular}


Hamada, et al.,

Table 2: Grain yield (ardab/feddan) of the advanced stem rust resistance yield trials in 2010/2011 growing season.

\begin{tabular}{|c|c|c|c|c|c|c|c|c|c|}
\hline \multirow[t]{2}{*}{ Cultivar } & \multicolumn{8}{|c|}{ Locations } & \multirow[t]{2}{*}{ Mean } \\
\hline & Sakha & Gemmeiza & $\begin{array}{l}\text { Kafr El- } \\
\text { Hamam }\end{array}$ & Sids & Mallawy & Shandaweel & Noubaria & Boustan & \\
\hline Misr 1 & 20.48 & 24.48 & 30.00 & 35.58 & 28.19 & 26.64 & 20.27 & 8.07 & 24.21 \\
\hline Misr 2 & 18.60 & 27.16 & 32.00 & 38.59 & 27.74 & 32.62 & 17.54 & 11.40 & 25.70 \\
\hline Sakha 93 & 19.26 & 18.90 & 22.80 & 35.07 & 25.69 & 24.37 & 15.94 & 5.20 & 20.90 \\
\hline Giza 168 & 17.98 & 21.68 & 26.00 & 33.82 & 27.25 & 26.90 & 16.07 & 8.80 & 22.31 \\
\hline Mean & 19.08 & 23.06 & 27.70 & 35.77 & 27.22 & 27.63 & 17.46 & 8.37 & 23.28 \\
\hline LSD 5\% & 3.59 & 1.49 & 2.11 & 2.96 & 2.27 & 2.69 & 2.55 & 1.67 & 2.91 \\
\hline
\end{tabular}

Table 3: Grain yield (ardab/feddan) of the preliminary yield trials in 2011/2012 growing season.

\begin{tabular}{|c|c|c|c|c|c|c|c|c|c|c|}
\hline \multirow[b]{2}{*}{ Cultivar } & \multicolumn{9}{|c|}{ Locations } & \multirow[b]{2}{*}{ Mean } \\
\hline & Sakha & $\begin{array}{c}\text { Etai } \\
\text { El- } \\
\text { Baroud }\end{array}$ & $\begin{array}{c}\text { Kafr } \\
\text { El- } \\
\text { Hamam }\end{array}$ & Gemmeiza & Sids & Mallawy & Shandaweel & Mattana & Nubaria & \\
\hline Misr 1 & 26.29 & 23.89 & 25.42 & 33.41 & 27.49 & 24.08 & 22.12 & 28.22 & 23.63 & 26.06 \\
\hline Misr 2 & 22.49 & 24.39 & 25.77 & 33.01 & 26.56 & 23.22 & 22.06 & 29.09 & 20.56 & 25.24 \\
\hline Sids 12 & 21.88 & 19.69 & 25.70 & 30.16 & 27.68 & 23.80 & 25.16 & 23.63 & 19.03 & 24.08 \\
\hline Mean & 23.55 & 22.66 & 23.63 & 32.19 & 27.24 & 23.70 & 23.11 & 26.98 & 21.07 & 24.90 \\
\hline LSD $5 \%$ & 1.80 & 2.06 & 2.79 & 5.02 & 2.65 & 2.81 & 4.09 & 2.49 & 3.51 & 25.07 \\
\hline
\end{tabular}

Data indicated that the grain yield of Misr 1 and Misr 2 exceeded the check cultivar Sids 12 by the respected percentages of 20.2 and $2.8 \%$ at Sakha, 21.3 and $32.9 \%$ at Etai El-Baroud, 10.8 and $9.5 \%$ at Gemmeiza, 19.4 and $23.1 \%$ at Mattana and by 14.9 and $8.0 \%$ at Noubaria as a new reclaimed land. In Kafr El-Hamam and Sids locations Misr 1 and Misr 2 yielded almost the same as the check cultivar Sids 12 . On the other hand, the two new cultivars yielded less than Sids 12 at Shandaweel. However, the average grain yield of Misr 1 and Misr 2, all over the nine locations, were higher than that of Sids 12 by 3.2 and $8.2 \%$, respectivelt.

Misr 1 and Misr 2 were compared with the commercial cultivars Gemmeiza 11, Sids 12 and Sids 13 in 17 advanced yield trials, covering most of wheat cultivated areas in Egypt, in 2011/2012 growing season, The results are shown in Table 4.

The two new cultivars, Misr 1 and Misr 2, often performed well and yielded higher grain yield in almost of the 17 locations. They yielded ethier higher than the check 
cultivars or almost the same as them, excepet in Tag El-Ezz where the new cultivars were less than the other bread wheat cultivars. That may be due to soil salinity in Tag El-Ezz and the two new cultivars may not be tolerant to soil salinity. Moreover, the average grain yield of the two new cultivares allover the 17 locations of the advanced yield trials were higher than those of the check cultivars. The average productivity of Misr 1 ranked the frist and it was higher than those of Gemmeiza 11, Sids 12 and Sids 13 by $0.4,5.1$ and $1.6 \%$, respectively, while Misr 2 ranked the second and it was higher than those of the respective cultivars by $2.5,7.3$ and $3.7 \%$.

The superiority of the two new cultivars Misr 1 and Misr 2 in grain yield comparing with the commercial wheat cultivars allover the country is confirming the effort of the breaders in Wheat Research Department to continue producing high yielding wheat cultivars to be grown under different environmental conditions in Egypt, with high resistance to the three rust diseases, especially the powerful and destroyer stem rust strain Ug 99.

Table 4: Grain yield (ardab/feddan) of the advanced yield trials in 2011/2012 growing seeason.

\begin{tabular}{|c|c|c|c|c|c|c|c|}
\hline \multirow[t]{2}{*}{ Location } & \multicolumn{5}{|c|}{ Cultivars } & \multirow[t]{2}{*}{ Mean } & \multirow{2}{*}{$\begin{array}{l}\text { LSD } \\
5 \%\end{array}$} \\
\hline & Misr 1 & Misr 2 & Gemmeiza 11 & Sids 12 & Sids 13 & & \\
\hline Sakha & 26.44 & 27.32 & 24.43 & 24.24 & 25.77 & 25.64 & 1.60 \\
\hline Etai El-Baroud & 23.20 & 23.73 & 23.47 & 21.53 & 20.93 & 22.57 & 2.34 \\
\hline Gemmeiza & 28.06 & 26.24 & 25.76 & 25.35 & 26.72 & 26.43 & 2.09 \\
\hline Sers El-Laian & 27.47 & 26.80 & 27.80 & 27.07 & 26.07 & 27.04 & 2.11 \\
\hline Tag El-Ezz & 20.67 & 22.33 & 26.00 & 24.67 & 24.67 & 23.67 & 2.34 \\
\hline Kafr El-Homam & 27.76 & 28.67 & 28.07 & 27.13 & 26.13 & 27.55 & 1.82 \\
\hline Bahteem & 19.07 & 19.27 & 19.80 & 17.27 & 18.33 & 18.75 & 2.43 \\
\hline Sids & 33.77 & 33.81 & 33.96 & 32.23 & 33.83 & 33.52 & 2.51 \\
\hline Mallawy & 25.90 & 25.13 & 29.47 & 23.34 & 24.58 & 25.68 & 2.37 \\
\hline Shandaweel & 29.03 & 29.20 & 28.92 & 29.35 & 28.19 & 28.94 & 1.96 \\
\hline Mattana & 29.50 & 32.93 & 32.93 & 28.20 & 32.77 & 31.27 & 2.85 \\
\hline Kom Ombo & 25.40 & 27.40 & 24.00 & 25.00 & 23.87 & 25.13 & 1.93 \\
\hline Noubaria & 23.00 & 23.00 & 19.33 & 15.33 & 17.13 & 19.56 & 3.26 \\
\hline New Valley & 16.33 & 16.05 & 14.61 & 15.57 & 15.48 & 15.61 & 0.42 \\
\hline Assiut & 13.43 & 13.67 & 13.03 & 13.60 & 13.83 & 13.51 & 1.82 \\
\hline East Ewynat & 15.11 & 16.99 & 12.29 & 15.21 & 19.89 & 15.90 & 0.76 \\
\hline Ismaelia & 7.63 & 7.47 & 6.42 & 7.65 & 7.50 & 7.33 & 0.44 \\
\hline Mean & 23.05 & 23.53 & 22.96 & 21.93 & 22.69 & 22.83 & 1.94 \\
\hline
\end{tabular}


The results in Tables 5, 6 and 7 show the average grain yield of Misr 1 , Misr 2 and other bread wheat commercial cultivars in the varietal verification yield trials in three consecutive growing seasons from $2010 / 2011$ to $2012 / 2013$. The varietal verification yield trials were carried out in a total number of 89 trials covering all wheat growing areas in old and new lands in 22 governorates, in addition to Noubaria and East Ewynat.

The results in Table 5 proved that the new bread wheat cultivars Misr 1 and Misr 2 surpassed the commercial cultivars and the yield potentiality of the new cultivars was more than the local checks Giza 168, Sakha 93 and Sids 12 in old and new land in 2010/2011 growing season.

In 2011/2012 growing season, the two new cultivars confirmed there superiority and produced higher grain yield (Table 6). In the over all mean of this season, Misr 1 yielded more than the other three checks by 7.9, 13.9 and $9.5 \%$ over Giza 168, Sids 13 and Shandaweel 1, respectively, while Misr 2 yielded $9.6,12.0$ and $11.3 \%$ more than the respective check cultivars.

Table 5: Grain yield (ardab/feddan) of varietal verification yield trials in 2010/2011 growing season.

\begin{tabular}{|l|c|c|c|c|c|c|c|}
\hline Governorates & $\begin{array}{c}\text { No. } \\
\text { experiments }\end{array}$ & \multicolumn{7}{|c|}{ Cultivars } & Mean \\
\cline { 3 - 7 } & & Misr 1 & Misr 2 & Giza 168 & Sakha 93 & Sids 12 & \\
\hline El-Behira & 2 & 21.20 & 21.84 & 21.70 & 21.02 & 21.77 & 21.51 \\
\hline Kaffer El-Sheekh & 2 & 20.26 & 20.19 & 19.46 & 17.80 & 18.60 & 19.26 \\
\hline El-Gharbia & 2 & 23.10 & 23.80 & 22.42 & 20.30 & 25.20 & 22.96 \\
\hline El-Menofia & 2 & 24.64 & 24.78 & 22.51 & 23.23 & 22.47 & 23.53 \\
\hline El-Qalyobia & 2 & 30.39 & 23.38 & 27.97 & 22.71 & 26.54 & 26.20 \\
\hline Giza & 2 & 22.40 & 22.40 & 25.90 & 25.20 & 21.80 & 23.54 \\
\hline Fayoum & 2 & 20.51 & 23.87 & 16.10 & 16.24 & 17.01 & 18.75 \\
\hline Bani Sewef & 3 & 21.93 & 21.73 & 16.80 & 20.10 & 20.10 & 20.13 \\
\hline El-Menia & 2 & 26.88 & 21.56 & 27.16 & 23.94 & 27.16 & 25.34 \\
\hline Assiut & 1 & 18.20 & 17.60 & 18.75 & 17.60 & 21.60 & 18.75 \\
\hline Sohag & 1 & 12.88 & 21.00 & 20.16 & 17.92 & 15.68 & 17.53 \\
\hline Awan & 1 & 12.10 & 15.90 & 16.00 & 16.80 & 16.00 & 15.36 \\
\hline Mean of old land & & 21.21 & 21.50 & 21.24 & 20.24 & 21.16 & 21.07 \\
\hline \multicolumn{7}{|c|}{ New land } \\
\hline Alexandria & 1 & 16.58 & 18.15 & 13.66 & 12.07 & 15.15 & 17.38 \\
\hline Demiatta & 2 & 9.52 & 12.52 & 13.60 & 11.79 & 13.44 & 18.06 \\
\hline Port Said & 1 & 20.66 & 21.84 & 17.18 & 19.60 & 25.27 & 22.34 \\
\hline Suez & 1 & 19.60 & 24.02 & 19.65 & 21.67 & 21.67 & 23.98 \\
\hline Bani Sewef & 1 & 15.40 & 14.00 & 14.00 & 15.40 & 12.60 & 19.33 \\
\hline Mean of new land & & 16.35 & 18.11 & 15.62 & 16.11 & 17.63 & 17.84 \\
\hline Allover mean & $28)$ & 19.78 & 20.50 & 19.59 & 19.02 & 20.12 & 20.82 \\
\hline
\end{tabular}


Misr 1 and misr 2: two new, high yielding and rust resistant bread wheat cultivars

Table 6: Grain yield (ardab/feddan) of verification yield trials in 2011/2012 growing season.

\begin{tabular}{|c|c|c|c|c|c|c|c|}
\hline \multirow[t]{2}{*}{ Governorates } & \multirow{2}{*}{$\begin{array}{c}\text { No. of } \\
\text { experiments }\end{array}$} & \multicolumn{5}{|c|}{ Cultivars } & \multirow[t]{2}{*}{ Mean } \\
\hline & & Misr 1 & Misr 2 & Giza 168 & Sids 13 & Shandaweel 1 & \\
\hline \multicolumn{8}{|c|}{ Old land } \\
\hline Alexandria & 2 & 19.80 & 20.60 & 22.26 & 19.32 & 20.65 & 20.53 \\
\hline El-Behira & 2 & 26.26 & 24.78 & 20.86 & 23.12 & 23.94 & 23.79 \\
\hline Kaffer El-Sheekh & 4 & 20.65 & 19.71 & 22.52 & 21.58 & 21.21 & 21.13 \\
\hline El-Gharbia & 2 & 27.07 & 35.32 & 22.23 & 24.66 & 30.00 & 27.86 \\
\hline El-Dakahlia & 2 & 21.45 & 21.65 & 21.68 & 22.29 & 16.80 & 20.77 \\
\hline El-Menofia & 3 & 25.68 & 24.66 & 24.12 & 23.47 & 23.75 & 24.34 \\
\hline EI-Qalyobia & 2 & 31.58 & 31.78 & 24.97 & 29.37 & 25.90 & 28.72 \\
\hline Giza & 2 & 28.70 & 30.10 & 29.05 & 26.60 & 28.35 & 28.56 \\
\hline Fayoum & 2 & 27.89 & 25.90 & 27.65 & 29.30 & 26.02 & 27.35 \\
\hline Bani Sewef & 2 & 22.35 & 20.79 & 19.25 & 17.85 & 19.90 & 20.03 \\
\hline El-Menia & 1 & 27.07 & 22.79 & 21.41 & 21.27 & 20.12 & 22.53 \\
\hline Assiut & 1 & 23.18 & 20.38 & 24.32 & 21.39 & 23.80 & 22.61 \\
\hline Sohag & 1 & 18.76 & 23.80 & 22.40 & 19.88 & 21.00 & 21.17 \\
\hline Awan & 1 & 16.00 & 13.70 & 16.8 & 15.90 & 17.50 & 15.98 \\
\hline Mean of old land & & 24.03 & 24.00 & 22.82 & 22.57 & 22.78 & 23.24 \\
\hline \multicolumn{8}{|c|}{ New land } \\
\hline Noubaria & 1 & 20.01 & 19.13 & 17.73 & 21.00 & 20.53 & 19.68 \\
\hline Demiatta & 1 & 17.88 & 21.28 & 10.08 & 10.36 & 11.20 & 14.16 \\
\hline Port Said & 1 & 19.90 & 26.96 & 17.89 & 18.9 & 17.50 & 20.23 \\
\hline Ismaelia & 1 & 21.70 & 20.30 & 24.5 & 19.45 & 18.76 & 20.94 \\
\hline Suez & 1 & 21.28 & 19.60 & 17.64 & 18.20 & 17.64 & 18.87 \\
\hline Bani Sewef & 1 & 21.03 & 18.29 & 18.77 & 15.48 & 15.11 & 17.74 \\
\hline Qena & 1 & 14.00 & 17.36 & 11.40 & 8.40 & 15.60 & 13.35 \\
\hline New Valley & 1 & 15.60 & 14.10 & 18.00 & 14.00 & 15.11 & 15.36 \\
\hline Mean of new land & & 18.93 & 19.63 & 17.00 & 15.72 & 16.43 & 17.54 \\
\hline Allover mean & (35) & 21.48 & 21.82 & 19.91 & 19.15 & 19.61 & 20.39 \\
\hline
\end{tabular}


Hamada, et al.,

The results of the third growing season (2012/2013) in Table 7 confirmed the obtained results in the previous two growing seasons for the superiority of Misr 1 and Misr 2 in producing higher grain yield than the cultivated cultivars.

In overall means, the grain yield the new released cultivars Misr 1 and Misr 2 exceeded those of checks wheat cultivars in old and new lands. In general, the tested locations the average grain yield of Misr 1 and Misr 2, therefore, exceded the average grain yields of Giza 168, Sids 13 and Shandaweel 1.

Table 7: Grain yield (ardab/feddan) of verification yield trials in 2012/2013 growing season.

\begin{tabular}{|c|c|c|c|c|c|c|c|c|}
\hline \multirow[t]{2}{*}{ Governorates } & \multirow{2}{*}{$\begin{array}{c}\text { No. of } \\
\text { experiments }\end{array}$} & \multicolumn{6}{|c|}{ Cultivars } & \multirow[t]{2}{*}{ Mean } \\
\hline & & Misr 1 & Misr 2 & Sids 12 & Sids 13 & Sids 14 & Shandaweel 1 & \\
\hline \multicolumn{9}{|c|}{ Old land } \\
\hline Kafr El-Sheikh & 2 & 21.24 & 19.71 & 17.99 & 18.77 & 18.83 & 18.80 & 19.22 \\
\hline Demiatta & 1 & 21.75 & 21.19 & 17.90 & 21.00 & 19.83 & 18.08 & 19.96 \\
\hline Al-Gharbya & 1 & 26.60 & 29.40 & 22.40 & 23.80 & 22.4 & 23.80 & 24.73 \\
\hline El-Menofeya & 2 & 24.78 & 24.46 & 22.56 & 23.63 & 22.26 & 17.79 & 22.58 \\
\hline El-Behira & 1 & 23.80 & 23.52 & 22.40 & 23.80 & 21.00 & 22.12 & 22.77 \\
\hline Alexandria & 1 & 24.15 & 15.47 & 15.89 & 18.55 & 18.55 & 19.25 & 18.64 \\
\hline Al-Qalyobia & 2 & 27.72 & 29.29 & 30.42 & 28.12 & 24.72 & 26.91 & 27.86 \\
\hline Al-Sharkia & 2 & 23.78 & 23.10 & 22.94 & 21.45 & 22.47 & 21.15 & 22.48 \\
\hline El-Dakahleya & 1 & 21.90 & 12.14 & 22.68 & 24.08 & 17.22 & 21.98 & 20.00 \\
\hline Giza & 2 & 28.00 & 21.70 & 28.35 & 22.95 & --- & 21.70 & 24.54 \\
\hline Al-Fayuom & 2 & 20.41 & 27.27 & 21.10 & 24.94 & 24.50 & 29.78 & 24.67 \\
\hline El-Mania & 1 & 26.60 & 27.16 & 28.00 & 23.52 & 26.60 & 24.92 & 26.13 \\
\hline Qena & 1 & 16.52 & 17.80 & 16.52 & 16.52 & 17.72 & 20.86 & 17.66 \\
\hline Luxer & 1 & 28.49 & 17.30 & 27.72 & 22.82 & 23.51 & 23.84 & 23.95 \\
\hline Aswan & 1 & 16.10 & 15.00 & 14.70 & 17.10 & 14.70 & 16.90 & 15.75 \\
\hline Mean of old land & & 23.46 & 21.63 & 22.10 & 22.07 & 21.02 & 21.86 & 22.06 \\
\hline \multicolumn{9}{|c|}{ New land } \\
\hline Suez & 1 & 21.00 & 21.28 & 20.44 & 19.32 & 19.60 & 18.20 & 19.97 \\
\hline Port Said & 1 & 26.01 & 30.48 & 23.05 & 23.12 & 16.67 & 26.70 & 24.34 \\
\hline Alexandria & 1 & 10.01 & 18.69 & 19.46 & 19.81 & 22.82 & 18.27 & 18.18 \\
\hline New Valley & 1 & 14.81 & 14.81 & 18.31 & 15.40 & 14.80 & 15.99 & 15.69 \\
\hline East Ewynat & 1 & 10.20 & 10.4 & 10.20 & 9.20 & 10.9 & 9.50 & 10.07 \\
\hline Mean of new land & & 16.41 & 19.13 & 18.29 & 17.37 & 16.96 & 17.73 & 17.65 \\
\hline Allover mean & (26) & 19.94 & 20.38 & 20.20 & 19.72 & 18.99 & 19.80 & 19.86 \\
\hline
\end{tabular}


Stability parameters for grain yield:

Stability parameters for grain yield of the advanced yield trials in 2011/ 2012 growing season were calculated according to Eberhart and Russell (1966). The stable cultivar was defined as one which had a high average performance over a wide range of environments, and the regression coefficient of equal one and no deviation from regression mean square. The results in Table 8 reveled that the new cultivars Misr 1 had better stability parameters at Delta, Middle and Upper Egypt and over all Egypt. On the other hand, Misr 2 had good stability parameters at Delta and out valley in the new land. Therefore, they could be recommended for planting in those environments.

Table 8: Grain yield stability parameters for Misr 1 and Misr 2 with the dominating wheat cultivars in 2010/2011 and 2011/2012 growing seasons.

\begin{tabular}{|c|c|c|c|c|}
\hline \multirow[t]{2}{*}{ Region } & \multirow[t]{2}{*}{ Cultivar } & \multirow[t]{2}{*}{ Grain yield } & \multicolumn{2}{|c|}{ Stability parameters } \\
\hline & & & $b$ & $S^{2} d$ \\
\hline \multirow{6}{*}{ Delta } & Misr 1 & 24.10 & 1.024 & -0.689 \\
\hline & Misr 2 & 24.76 & 0.812 & 0.362 \\
\hline & Gemmeiza 11 & 25.05 & 0.555 & 2.158 \\
\hline & Sids 12 & 23.86 & 0.749 & 2.510 \\
\hline & Sids 13 & 24.38 & 0.921 & 1.477 \\
\hline & L.S.D $5 \%$ & 2.11 & & \\
\hline \multirow{6}{*}{$\begin{array}{l}\text { Middle and } \\
\text { Upper Egypt }\end{array}$} & Misr 1 & 28.52 & 0.887 & -0.478 \\
\hline & Misr 2 & 29.69 & 0.758 & 1.802 \\
\hline & Gemmeiza 11 & 29.26 & 0.929 & 1.609 \\
\hline & Sids 12 & 27.63 & 0.872 & -0.599 \\
\hline & Sids 13 & 28.20 & 1.017 & 1.563 \\
\hline & L.S.D $5 \%$ & 2.33 & & \\
\hline \multirow{6}{*}{$\begin{array}{l}\text { Out valley (new } \\
\text { land) }\end{array}$} & Misr 1 & 14.50 & 1.069 & 1.523 \\
\hline & Misr 2 & 14.84 & 1.291 & -0.285 \\
\hline & Gemmeiza 11 & 13.14 & 0.904 & 0.743 \\
\hline & Sids 12 & 13.47 & 0.600 & 1.470 \\
\hline & Sids 13 & 14.77 & 0.787 & 4.199 \\
\hline & L.S.D 5\% & 1.34 & & \\
\hline \multirow{6}{*}{ Over all Egypt } & Misr 1 & 22.57 & 1.011 & 0.894 \\
\hline & Misr 2 & 23.30 & 1.049 & 2.048 \\
\hline & Gemmeiza 11 & 22.78 & 1.064 & 3.960 \\
\hline & Sids 12 & 21.93 & 0.919 & 4.350 \\
\hline & Sids 13 & 22.69 & 0.947 & 3.458 \\
\hline & L.S.D. $5 \%$ & 1.94 & & \\
\hline
\end{tabular}




\section{Rust Disease Reaction:}

Data in Table 9 represented the average response of bread wheat cultivar Misr 1 and Misr 2 and three bread wheat check cultivars to leaf and stem rust at Sakha in $2011 / 2012$ growing season. Sakha is considered a hot spot of wheat rust diseases in Egypt.

The obtained data revealed that Misr 1 and Misr 2 were highly resistant to leaf and stem rusts. These results confirmed that the new bread wheat cultivars Misr 1 and Misr 2 have high resistant degrees to leaf and stem rust diseases when they tested in the hot spots in some African countries.

Moreover, the calculated average coefficient of infection (ACI) for leaf and stem rust diseases for Misr 1 and Misr 2 and three commercial cultivars at adult stage at Sakha, Gemmeiza, Nubaria, Kafr El-Hamam and Sids agricultural research stations in $2011 / 2012$ growing season (Table 10) proved that the new bread wheat cultivars have high resistance to both leaf and stem rust diseases.

Table 9: Rust reaction of Misr 1 and Misr 2 and three commercial cultivars to leaf and stem rusts in Sakha Agricultural Research Station in 2011/2012 growing season.

\begin{tabular}{|l|c|c|}
\hline \multirow{2}{*}{ Cultivars } & \multicolumn{2}{|c|}{ Rust } \\
\cline { 2 - 3 } & Leaf rust & Stem rust \\
\hline Misr 1 & 0 & 0 \\
\hline Misr 2 & $5 \mathrm{~S}$ & 0 \\
\hline Gemmeiza 11 & $10 \mathrm{~S}$ & 0 \\
\hline Sids12 & Tr R & 0 \\
\hline Sids 13 & $5 \mathrm{MR}$ & 0 \\
\hline
\end{tabular}

Table 10: Mean of average coefficient of leaf and stem rust diseases infection at adult stage for Misr 1 and Misr 2 and three commercial wheat cultivars at five locations in 2011/2012 growing season.

\begin{tabular}{|l|l|c|c|c|c|c|}
\hline \multirow{3}{*}{ Rust } & Location & \multicolumn{6}{|c|}{ Cultivar } \\
\cline { 2 - 7 } & & Misr 1 & Misr 2 & Gemmeiza 11 & Sids 12 & Sids 13 \\
\hline \multirow{4}{*}{ Leaf rust } & Sakha & 0 & $5 \mathrm{~S}$ & $10 \mathrm{~S}$ & $\operatorname{Tr} \mathrm{R}$ & $5 \mathrm{Mr}$ \\
\cline { 2 - 7 } & Gemmeiza & 0 & 0 & 0 & 0 & 0 \\
\cline { 2 - 7 } & Nubaria & $\operatorname{Tr} \mathrm{S}$ & 0 & $40 \mathrm{~S}$ & 0 & $10 \mathrm{~S}$ \\
\cline { 2 - 7 } & Kafr El-Hamam & 0 & 0 & $30 \mathrm{~S}$ & $40 \mathrm{~S}$ & $\operatorname{Tr} \mathrm{R}$ \\
\cline { 2 - 7 } & Sids & $\operatorname{Tr} \mathrm{S}$ & $\operatorname{Tr}$ Mr & 0 & $10 \mathrm{Ms}$ & 0 \\
\hline \multirow{5}{*}{ Stem rust } & 0 & 0 & 0 & 0 & 0 \\
\cline { 2 - 7 } & Sakha & 0 & 0 & $5 \mathrm{Mr}$ & $5 \mathrm{~S}$ & 0 \\
\cline { 2 - 7 } & Gemmeiza & 0 & 0 & 0 & 0 & $5 \mathrm{R}$ \\
\cline { 2 - 7 } & Nubaria & 0 & 0 & 0 & 0 & 0 \\
\cline { 2 - 7 } & Kafr El-Hamam & 0 & 0 & 0 & 0 & 0 \\
\cline { 2 - 7 } & Sids & & & & &
\end{tabular}


Distinctness Uniformity and Varieties of plants (UPOV). This test was Stability tests (DUS):

This test was carried out by the Central Administration of Seed Certification (CASC) for two successive seasons according to the International Union for the Protection of new done before registration and releasing the the two new cultivars. The results of the tests and the description of the new wheat cultivars Misr 1 and Misr 2 are in in Table 11.

Table 11: Description of Misr 1 and Misr 2 according to the International Union for the Protection of new Varieties of plants (UPOV).

\begin{tabular}{|c|c|c|c|}
\hline \multirow[t]{2}{*}{ No. } & \multirow[t]{2}{*}{ Characteristics } & \multicolumn{2}{|c|}{ Description } \\
\hline & & Misr 1 & Misr 2 \\
\hline 1 & Pigmentation of coleoptiles & 1 & 1 \\
\hline 2 & Growth habit & 1 & 1 \\
\hline 3 & Anthocyanin coloration of flag leaf auricles. & 1 & 1 \\
\hline 4 & Flag leaf rolling & 3 & 3 \\
\hline 5 & Number of days to $50 \%$ heading & 5 & 3 \\
\hline 6 & Glaucosity of flag leaf sheath & 7 & 5 \\
\hline 7 & Glaucosity of the spike & 3 & 3 \\
\hline 8 & Glaucosity of ear neck & 5 & 5 \\
\hline 9 & Plant height & 5 & 7 \\
\hline 10 & Thickness of parenchyma wall & 3 & 3 \\
\hline 11 & Spike shape & 1 & 1 \\
\hline 12 & Density of ear & 3 & 5 \\
\hline 13 & Spike length excluding awns & 5 & 5 \\
\hline 14 & Presence of awns & 3 & 3 \\
\hline 15 & Awns length & 5 & 5 \\
\hline 16 & Spike color at maturity & 1 & 1 \\
\hline 17 & Hair density at the lower edge of the rachis & 3 & 3 \\
\hline 18 & Width of lower glume & 5 & 5 \\
\hline 19 & Sheulder shape of glume & 1 & 3 \\
\hline 20 & Length of glume beak & 3 & 1 \\
\hline 21 & Shape of glume beak & 1 & 3 \\
\hline 22 & Hair density in the lower glume & 3 & 5 \\
\hline 23 & Shape of lemma beak & 3 & 5 \\
\hline 24 & Grain color & 1 & 2 \\
\hline 25 & Grain color density at phenol test & -- & -- \\
\hline 26 & Seasonal type & 3 & 3 \\
\hline
\end{tabular}




\section{REFERENCES}

Eberhart, S.A. and W.A. Russell (1966). Stability parameters for comparing varieties. Crop Sci., 6:36-40.

Hamada, A.A., A.M. Abo-Warda, S.A. Abd El-Majeed, E.A.M. El-Sayed, M.K. Meshref, M.B. Towfelis, H.A. Ashoush, H.I. Hendawy, H.S.A. El-Borhamy, A.K.M. Rady, A.M.M. Moussa, W.A.M. El-Awady, N.A.R. Abd El-Nour, S. H. Abo El-Ela, R.M.A. Kumber, A.A. Swelam, I.A. Amin, S.A.M. Seleem, M.A.I. Khaled, S.M.A. Abd El-Dayem, S.M. Hamad, S.M. Hassan, M.E. Abd El-Rahman, R.A. Ramadan, S.A. El-Sawy, M.A. ElMaghraby, M.A. Hassan, A.M. Abd elAal, A.A. Murod, M.Y. Moubark, A.T.H. Moustafa, T.H. Abd El-Kreem, H.M. ElGharabawy, M.M. Zakaria, A.A. Hagras, M.S. Mahmoud, A.M. Morsy, A.A. Mahmoud, M A. Aglan, E.A.M. Abd ElHamid, W.Z. Farahat, K.I.M. Gad, K.E. Ibrahem, M.N.T. Abd El-Kader, S.N. Nathan, I.S.M. Abd El-Latif, E.G. Galal, M.M.M. Abd El-Salam, S.T. Eesa, G.A.N. Abd El-Rahman, M.N.A. El-Hawary, M.A.H. Darweesh, M.Y. El-Masry, A.G. Abd El-Rady, A.S. Abd El-Hamed, M.M. Mohamed, M.M. Mokhtar, A.A. Zen ElAbdeen, M.S. Salus, S.A. Mohamed, M.M.M. Yaseen, A.A. Gomaa, E.H. Ghanem, M.G. Mosaad, M.A. El-Menofy, S.K. Mahmoud, A.A. Khattab, A. Abd ElLatif, N.S. Hanna, M.A. Moussa, M.S. Saleh, M.A. Gouda, A.El-Hag, F.A. Hefnawy, A. Ageez, S.A. Ali, N. Abd ElFattah, M.A. Mostafa, T. Shehab El-Din, M.A.A. Salem, M. A. M. Abo-Sheref, S.R.S. Sabry, M.M. Abd El-Aleem, M.S. Sharshar, A.M. Gad-Allah, G. ElShaarawy, E.M. Sadek, A.M. Tammam, I.A. Imbaby, M.M. El-Shamy (2015). Giza 171: A new high yielding bread wheat cultivar. Egypt. J. Plant Breed. 19(7):2063-2079.
Johnston, T. and L.E. Browder (1966). Seventh revision of the international register of physiologic races of Puccinia recondita f.sp. tritici. Plant Dis. Res., 50:756-760.

Mosaad, M., M. El- Monofy, T. Shehab ElDin, R. Mitkees, M. Mahrous, A.Hamada, A. Ageez, A. Bassiouni, M. El-Shami, M. Abdel-Aleem, M. Eid, A. Abdel-Ghani, M. Eskander, N. Hanaa, S. Sabry, A. AbdelLatif, M. Sharshr, Iman Sadek, M. Mostafa, A. Abo-Warda, Y. Abdel-Gwad, A. Mousa, S. Abdel-Majeed, A. Tammam, Najwa Abdel-Fattah, $M$. Moshref, E. El-Sayed, H. Ashoush, M. Towfeeles, Hayam Mahjoub, A. Moustafa, F. Hefnawy, H. Hendawy, S. Ali, A. Abdel-Karim, A. Khattab, M. Abdel-Fattah, A. Menshawy, H. ElBorhamy, A. Gomaa, F. O. Khalil, Kadria Hegazi, A. Ali, Enayat Ghanem, S. Mahmoud and M. Khalifa (2000). Gemmeiza 9: A new Egyptian high yielding and rust resistant bread wheat cultivar for Delta region. J. Agric. Sci., Mansoura Univ.,25(12):7407-7419.

Pretorius, Z.A., R.P. Singh, W.W. Wagoire, S.T. Payne. 2000. Detection of virulence to wheat stem rust resistant gene $\mathrm{Sr} 31$ in Pacccinia graminis f. sp. tritici in Uganda. Plant Diseases. 84:203.

Roelfs, A.P. and T.W. Martens (1988). An international system of nomenclature for Puccinia graminis f. sp. tritici.. Phytopathology. 78:526-533.

Saari, E.E. and R.D. Wilcoxson (1974). Plant disease situation of high yielding durum wheat in Asia and Africa. Arr. Rev. Phyto., 2:47-68.

Shehab El-Din, T., R.A. Mitkees, M.M. ElShamy, M.A. Gouda, M.M. AbdeAleem, A.M. Abdel-Ghani, N.S. Hanna, Iman M.M. Sadek, A.M. Abo-Warda, M.Kh. Mosherf, E.A.M. El-Sayed, Hayam S. Mahgoub, A.K. Mostafa, M.G. Mosaad, 
A.H. Bassiouni, M.M.A. El-Monofy, S.Kh. Mahmoud, M.A. Mahrous, A,A, Ageez, M.A.M. Eid, M.H. Iskandar, M.A. Mostafa, A.A. Hamada, Y.G. Abdel- Gwad, A.M. Mousa, S.A. Abdel-Majeed, A.M. Tammam, Nagwa R. Abdel-Fatah, $\mathrm{H}$. Ashoush, F.A. Hefnawy, H. Hendawy, S. El-Din, M.B. Toweefles, A.A. AbdelKarim, A.A. Khattab, A.A. Gomaa, O.H.S. Khalil, Kadria F. Hegazi, Enayat $H$. Ghanem, A.A.Ali, F.F. El-Sayed, Ikhlas Safik and S. Aboel-Naga (1999). Sakha 93 and Giza 168: Two new high yielding and rust diseases resistant bread wheat cultivars. J. Agric. Sci., Mansoura Univ., 24:2157-2168.

Stakrnan, E.C., D.M. Stewart and W.Q. Loegering (1962). Identification of physiological races of Puccinia graminis var. tritici. U.S. Dept. Agrie. Res. Sew. J. S. E., 6173.

Steel. RGD. and J.H. Torrie (1960). Principles and procedures of Statistics. and Ed. Mc Graw-Hill Book Co. New York. 
مصر 1 ومصر 2: صنفان جديدان من قمح الخبز عاليا المحصول ومقاوما للصدأ

أسعد أحمد حماده، صلاح الدين احمد عبد المجيد، عز الدين عبد الرحمن محمد السيد، موريس بليع توفيليس، هانى سعد عبد الحميد البرهانى، وفاء عبد الحميا محمد العوضى، صباح حمزه أبو العلا، رضا محمد على السيد قمبر، عبد الله عبد المحسن سويلم، إبراهيم عبد الهادى أمين، صبرى احمد محمد سليم، سهير محمود حسن، صبحى محمد على عبد الدايم، سعيد محمد حماد، ماجدة السيد عبد الرحمن، سبد عبده الصاوى، منال عبد الصمد، ماهر عبد المنعم محمد على، عزه محمد عبد العال، محمد يوسف غنيم، عبد الفتاح عبد الرحمن مراد، هدى مصطفى الغرياوى، أحمد طه حسن مصطفى،

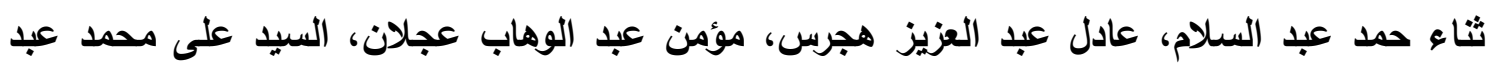
الحميد، خالد إبراهيم محمد جاد، وليد زكي اليماني فرحات، خالد الدمرداش إبراهيم، محمد مختار زكريا،

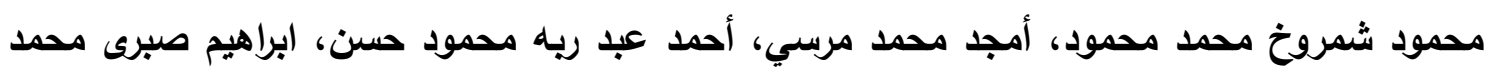
عبد اللطيف، شرين نبيل ناثان، محمد نويى طه عبد القادر، الحسيني غلاب جلال، محمد محى محمد عبد السلام، شريف ثابت عيسى، جيهان عبد الواحد نور الدين، محمد يوسف محمد يوسف، محمد عبد الكريم حسن درويش، اشرف صلاح عبد المجيد، أيمن جمال عبد الراضى، محمد مرعى محمد، مختار مراجع مختار جاب الله، محمد نبيل عوض الهوارى، موسى شوقى سالوس، احمد على زين العابدين، سيدهم عبد الخالق محمد، مصطقى تاج الدين شهاب، محمد مصطقى محمد يس، عبد العزيز ابراهيم عبد الصادق، السيد لطفى المصرى، أنس محمد صفاء الدين شرشر، عصام الدين معوض، ياسر سيد ابراهيم قبيصى، يوسف محسن فلتاؤوس، ياسر احمد الجوهرى، جمال محمد محمد سليمان، محمد سعيد أبو زيد جنيدى، عبد السلام أحمد جمعة، عنايات حسن غانم، موسى جرجس مسعد، عبد اللطيف

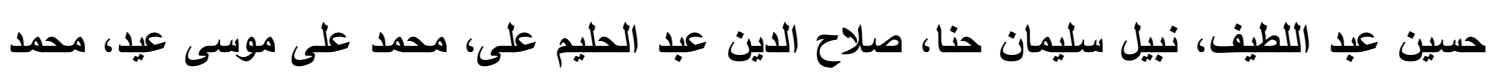

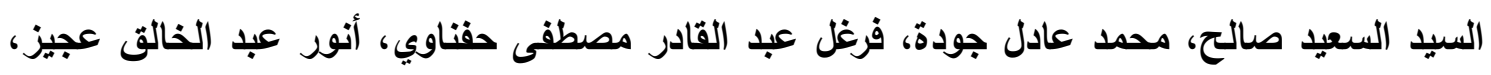

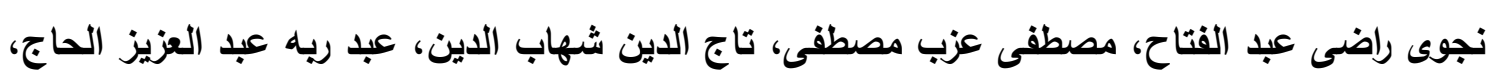
محروس عبد الغتى محروس، سامى رضا صابر صبرى، مسعد محمد محمود عبد العليم، محمد صفاء الاين شرشر، أحمد محمد جاد الله، جمال عبد الرازق محمد الثعراوى، إيمان محمد محمد صادق، أحمد محمد تمام، محمد عبد الكريم اسماعيل، ناديه عدلى رياض، أحمد محمد محمد موسى، حمدى إبراهيم هنداوى، رمضان عبد السلام، أبو بكر محمد على أبو ورده، حسن عبد اللطيف حسن عشوش، محمد

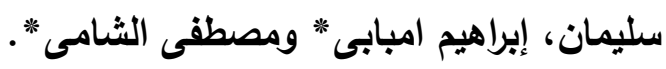

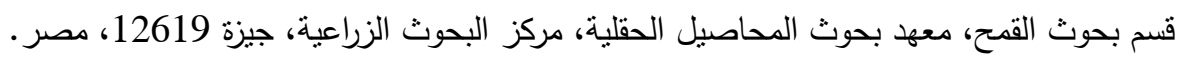

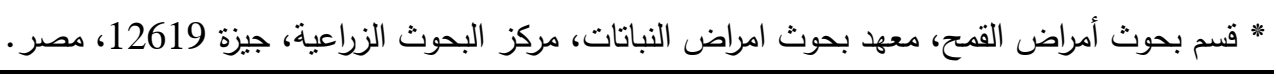


تم انتخاب صنفى قمح خبز جديدين هما مصر 1 ومصر 2 من سلالات قمح الخبز الواردة إلى قسم بحوث

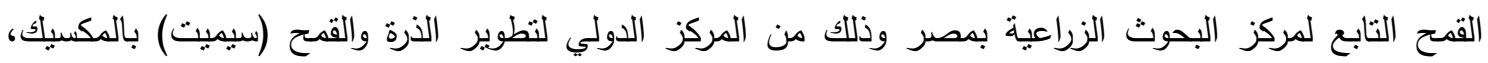
والمقاومة لأمراض الصدأ وبصفة خاصة سلالة صدأ الساق الأسود 99 Ug. وتم تقييم السلالتين الجديدتين

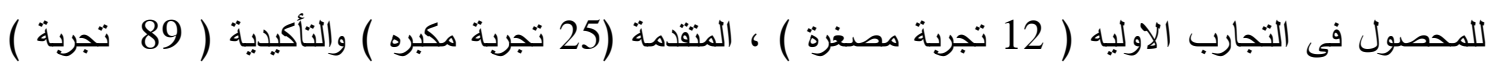
اعتبارا من الموسم الزراعي 2010/2009 وحتى الموسم 2013/2012، بالمقارنة بأصناف قمح الخبز المنزرعة. هذا وقد أوضحت النتائج أن محصول الحبوب للصنفين الجديدين مصر 1 ومصر 2 قد تفوق على محصول الحبوب لأصناف المقارنة في كل مناطق الاختبار ، وبصفة عامة كان محصول حبوب الصنفين الجديدين إعلى من

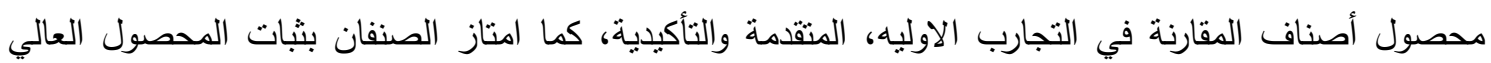
تحت مختلف الظروف البيئية التي يزرع فيها القمح في مصر • واختبار الصنفين الجديدين للإصابة بالصدأ الأصفر وصدأ الساق الأسود في أماكن انتتارها في مصر، أوغندا، كينيا وأثنوبيا أثنتا مقاومة عالية للأصداء. وبناء على فئى

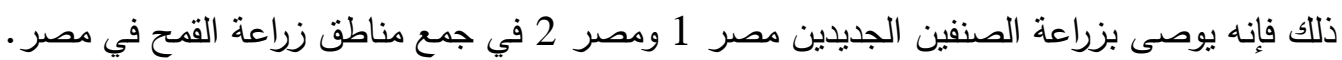

